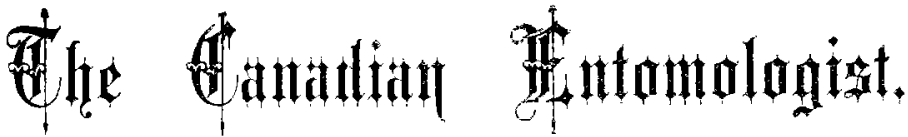

VoL. XXXIX. IONDON, APRIL, r907. No. 4.

\section{HABITS OF SOME MANITOBA "TIGER BEETLES" (CICINDELA).}

BY NORMAN CRIDDLE, AWEME, MANITOBA.

This paper is the result of two years' study and a number of years' collecting in the neighbourhood of Aweme, Manitoba. It has no pretence of being complete in all details or of taking in all the forms inhabiting the Province, a very small portion of which has yet been collected over. The species and varieties mentioned, with the exception of hirticollis and pusilia, have been under personal observation, and all have been collected within twelve miles of Aweme, which is in latitude $49^{\circ}, 42^{\prime}$; the height above the sea averaging about $\mathrm{I}, \mathrm{I} 80$ feet.

In working up the habits of these insects I have received much valuable information through the generous assistance of Prof. Wickham, to whom my grateful thanks are due. I am also under deep obligation to Mr. E. D. Harris for supplying me with much information.

The species are arranged according to Dr. W. Horn's Index.

In habits, the Manitoba, and probably all the North American species, conld be divided into two groups; namely, those which hatch out in August, or thereabouts, and hibernate, and those species, such as lepida, which appear from pupe towards the end of June and die before winter sets in.

This somewhat interesting difference in habit has not, so far as I am aware, received any marked atteution, though I am inclined to believe that it has been a factor of some importance in the modification of a number of species.

The individuals of the first of these groups, at the approach of winter, search out a suitable situation and excavate a hole in which they pass the winter. The depth of burrow varies considerably with the different species, and even to a marked cxtent in forms that are classed as subspecies. The choice of a locality for hibernation varies according to the species, but all seem to prefer a situation in which there is a slant facing the south, so that they get full advantage of the sun. In investigating the methods of hibernation I have found that a shallow hole dug in the 
vicinity of a Cicindela locality always proves productive, and that large numbers will congregate from all parts to seek their winter homes in such places. The hole, however, should be dug a month or more before the hibernating season commences.

In digging, the beetles loosen the earth with their mandibles, and use one leg at a time when kicking the earth back. For the first three to eight inches the hole is dug at au angle, after which it usually goes down in an almost perpendicular direction, though it often happens that when starting after an interval of rest the beetles will take a slightly different direction, so that the hole is never straight, but turns first one way and then another. For the first six to fifteen inches the earth is thrown out, but after this depth is reached the hole is gradually filled in moderately tightiy. From four to ten inches being leít unfilled at the bottom to enable the beetle to work its way out.

The hole is nearly always wide enough at all points to allow the betle to turn round, and is always so at the bottom. When the hole is completed, the beetle turns round and faces the top, ready for digging its way out the next spring, when it emerges in practically as perfect condition as when it went in.

A few species, and these closely related, probably dig below the usual frost liue, but many do not, as I have dug ont several kinds that were in the solid frozen ground and were quite motionless, and which took fully half an hour to become even moderately active in a warm place. All the hibernating forms become sluggish, and eventually torpid as the earth gets cold and frozen.

There are, no doubt, many belonging to this group that never leave their winter homes, especially those kinds that inhabit localities close to water. In fact, it is by no means an uncommon occurrence to find dead specimens of the previous year when digging out live ones. Hundreds were found hibernating in 5906 only five feet above low-water mark in the banks of the Assiniboine River, which the rise of the water in the spring would almost surely totally destroy.

The second of our groups contains strictly summer species, which do not pass the winter in the imago stage, but only as larve, possibly as pupæ or ova. There are, however, in the United States some species that are probably intermediate between tha iwo groujs, which either pass the winter in very shallow holes or under stones, fallen trees, etc., but these, though difficult to distinguish from the summer species, strictly belong to our first group. 
In $n$ c case can I find any evidence to warraut the belief that any of our native forms are double-brooded, and it seems highly probable that the same could be said of all North American Cicindelide. From my investigations I was inclined to think that no specimens emerged from pupæ in the springtime, but Mr. E. D. Harris writes that he has collected specimens in the early spring that "bear inmistakable evidence of very recent emergence from the pupa condition," and he suggests that these are belated specimens which failed to appear at the usual time in the early autumn.

I can give little information as to the habits of the larve. Most of, and probably all, the Manitoba Cicindelas pass one winter as Larva, and indications point in some cases to two winters being passed in this condition. Unfortunately, I am unable to write with exactitude in this matter, but think it well to draw attention to the subject.

The larve are by no means the helpless creatures out of their holes some writers think. 'lhey can crawl readily, and, undotibtedly, in some cases leave one hole and dig another. At the approach of winter they commence deepening their holes, and, like those of the beetles, when completed the holes vary in depth with the different species. In digging, the insects loosen the earth with the mandibles, and then shove that flat shovel-like structure of the head and prothorax under the loosened earth until sufficient has been received to make a load, when the insect turns round and works its way up, holding the "shovel" in a horizontal position until it gets level with the top of the hole, when the head and "shovel" is suddeniy jerked backwards, which throws the earth two or three inches away. Iarve that were watched took from 70 to I 3 seconds between each load of earth when the holes were about 14 inches deep.

The plates of the head and prothorax form a most interesting structure, which has apparently been specially modified for the purpose of digging and carrying earth to the surface.

For the first portion of the season most of the work is done at night or in the evening and early morning, but as the season advances digging is also done in the daytime, especially if the weather is cold. Usually larve are found digging a week or more later in the season than the imagoes. As the holes get deeper the sand becomes gradualiy piled up so that the insects are unable to throw it so far away, and at last the earth, by rolling back, blocks the entrance, though not, I believe, until the correct deptin has been attained, as in some cases the hole is built up 
through the loose sand. When finished the hole is usually blocked near the top, and in some cases further down, after which the larva retires to the bottom for the winter.

To a beginner the holes are much like those made by a burrowingspider, for which they usually pass. They can, liowever, be at once distinguished from these by the absence of web at the entrance, and nearly always by the formation of the heaps of sand thrown out. Those of spiders are nearly always in a complete circle, while those of Cicindela larva are either in one heap or in two opposite each other.

The larvæ are always enormously abundant in comparison with the bectles, which shows that large numbers must perish, though by what means I am unable to say.

The beetles are sometimes destroyed in large numbers by badgers.

The habits of each species, sub-species or aberration follow under separate headings.

Cicindela formosa, aber, Manitoba, I,eng.- The largest of our Manitoba tiger-beetles. This form is not very well differentiated from senerosa, and I have specimens of both before me that I am only able to separate with difficulty, though with the average specimen Manitoba is easily distinguished by the broadness of the elytral markings, which in some cases cover nearly two-thirds of the elytra. Some specimens also run rather closely to formosa in colour and markings. In newly-hatched specimens the anterior portion of the elytra is sparsely clothed with fine hairs.

'These handsome beetles are strong fliers. They usually inhabit the edges of sandy blow-outs where the vegetation is straggling and far between. The new brood appears about the second week in August, and is overlapped by the old brood to the extent of about ten days.

Manitoba is among the earlier kinds to commence winter quarters, choosing much the same locality as limbata, but in places rather more sheltered. For depth of hole this form stands out alone. The average depth of burrow from the entrance is 38 inches, in soft sand the depth is about 44 inches. The deepest hole measured was 47 inches, and the shallowest 25. Larvæ holes that probably belonged to this form were from 30 to 48 inches deep. They were in rather denser vegetation than where the beetles are usually found, but were close to blow-outs inhabited by Manitoba.

Manitoba has been noter feeding upon Disonycha uninquevithata, and upon other Crysonelide, as we-ll as upon ants. 
Cicindela venusta, Lec.-Dry sandy fields and small blow-outs in which there is some vegetation are the favourite habitations of venusta. This species is sometimes found in company with Manitoba in Manitoba localities, but Manitoba is seldom found in the favourite hunting-ground of venusta. Venusta is a strong flier, though not quite as strong as Manitoba. It is among our most common species, and is found throughsut the season. The old brood begins to disappear about the middle of July, and the new appears early in August. The old brood overlaps the new to a small extent. Small open places with a slope facing south are the spots most frequently selected for hibernation; burrows are also found among vegetation on the edges of drifting sand. The average depth of 49 specimens dug out was $19 \mathrm{~T} / 2$ inches, the deepest. 32 inches and the shallowest 12 inches. In soft sand about 22 inches is the average depth.

I believe the larve hibernate at greater depth than the beetles, but exact data are lacking owing to the similarity of some of the species.

Cicindela limbata, Say.-.-(One of the most abundant of our tigerbeetles, abounds on large sandy blow-outs where the veretation is scanty. It is sometimes found on very small patches of drifting soil, but is always much more plentiful on white sind that is constantly drifting. After high winds they are sometimes found in large numbers in hollows or anong grass on the opposite side from which the wind has been blowing. They are found copulating from carly in June to cuite late in July, often partly buried in the sand. 'Towards the end of July a great many die off, but some remain in activily until after the new brood has made its appearance during the first and second week of August, specimens of the old brood being at once recognized by the liardness of the elytra, which are also often partly discoloured in old specimens, while in the new they are soft, and make poor cabinet specimens for iwo weeks or more after they appear, but in this they differ little from other species.

Towards the end of August a few begin to dig out their winter homes, especialiy on small blow-outs where the ground is dark. By the tenth of September most of the specimens are at work in the above localities, but on white sand they remain tolerably numerous until the last of the month. In 1906 all had disappeared by the 6 th of October.

The places chosen for hibernation are at the edges of blow-outs, though, as a rule, in the soft sand. Slopes that are facing the sun at midday are muel preferred. The holes average ir inches from the entrance. 'The deepest measured was 17 inches, and the shallowest 7 inches. 
Limbata is one of the first species to make its appearance in the spring. They have been found in sunny spots on the $3^{\text {rd }}$ of April. Doubtless their early appearance is due to the shallowness of their burrows and the warmth of the sand when exposed to the sun.

The larve pass the winter in holes of about the same depth as the beetles. They can, however, stand much more cold, and remain active for nearly a month later. In 1906 the last was found digging on the 26 th of October, at a time when the ground was frozen to an inch in depth and the temperature was below freezing. A larva dug out on the 24 th of October dug to a depth of $4 \frac{\mathrm{T}}{2}$ inches in 18 hours, with probably large intervals of rest. Larve are often found in the middle of blow-outs, though they prefer to dig near grass or weeds.

Cicindela furpurea, sub-sp., limbalis, Klug.--In summer inhabits damp ground. The hills of pocketgophers (Geomyide) in meadows are favourite haunts. It is also found in company with repanda on wet roadways, and with 12 grttata on the banks of rivers. Copulation takes place in May. This iusect is nowhere common, and is nearly always found singly or in pairs. About the middle of September they seek out a somewhat drier spot than their ustal summer hunting-ground in which to pass the winter, and they are then found in many odd places. Edges of sandy blow-ouls, stubble fields, sand pits, dry roadways and clay banks are among the places where they have been discovered. In sand the depth of hole is about 16 inches, in clay it is 6 inches, and on the edge of roadways where the ground was hard and rooty two specimens were fomd hibernating mly 3 inches below the surface, while in sand the reepest hole was ig inches.

timualis is rather a late form to appear in the spring. The bectles first emerge from pupa in August.

Cicindela duodecinguttata, Dej.--An abundant species along river banks wherever there is mud or wet sand. They differ from repanda in preferring localities close to ruming streams, often going right to the water's edge in search of fooch. The form collected at $A$ weme has much the same markings as repanda, excepting that they are narrower and do not extend as much at the margin, some also have the markings broken more like the typical form.

I am indebted to Prof. Wickham for the determination of this species.

The winter lromes of 12 -grttata are nsually close to their summer ones, being dug into the river banks where there are open spots, from 
Four to twelve fect from the level of the river, With these species that dig into banks of streams the holes are usually somewhat on the slant. One hundred and forty-eight specimens were dug out, and their holes measured. In sandy soil these averaged 16 inches, deepest 20 inches, shallowest 10 inches. In clay or gravel the average depth was 7 inches, deepest 10 and shallowest 2 inches.

Two or three specimens were often found in the same hole, and $5^{\circ}$ or more might be dug out within the space of a square yard. I2-guttata is the latest of the Aweme tiger-beetles to hibernate, specimens in 1906 being still numerous on the $14^{\text {th }}$ of October, and a few were found quite active, just commencing to excavate burrows, as late as the 20 th of October, after heavy frosts.

I arva holes are usually very numerous all up the river banks near where the adults hibernate. The holes generally slant obliquely into the banks. They average in depth from 6 to 15 inches, but in stimmer time they are often only 4 or 5 inches deep. Both larve and imagoes must often perish in their winter homes when the water rises above them.

C. I2-guttata, sub-sp., repanda, Dej.-Common along muddy roadways and wet fields. I have found it in abundance along furrows and in wet spots in tall grain, and also on sand in wet localities, and in lesser numbers on rather muddy spots along river banks.

Repanda appears in the spring with $12-$ suttata, rather later than the other forms, probably owing to their habit of usually hibernating in cold, damp ground, which takes longer to warm up. The old brood overlaps the new to the extent of about ten days. The new brood begins to appear late in July and during the begiuning of August. They are one of the later tigers to libernate, and owing to their inhabiting wet spots they have often to seek winter quarters some distance away. They have been found hibernating fully half a mile from their summer huntinggrounds, and, no doubt, in some cases go much farther. Hillsides or banks with litile vegetation are usually chosen as winter quarters. In sandy localities repanda digs to an average deptly of 19 inches, the deepest hole cxamined being 22 inches, shallowest 18 . In clay the depth of hole is often only 6 or 8 inches, but when found in company with r2-guttata their holes average from 2 to 4 inches deeper than that species. Both r2-guttata and tranquebarica have been found in the same hole as repanda while hibernating. 
Cirindela hirticollis, Say.- $A$ single: specinen has been collected at Aweme, which was confused with olher species at the time. Unfortunately, no data are available as to habits or time of capture. From its appearance, however, I an convinced that it hibernates. Prof. Wickham says of this species: "Has much the same habits as repanda, but is less commonly found in the interior.":"

Cicindela tranquebarica, Herbst.-Found on open spots in almost all localities in small numbers. Dry land and wet land, sand, mud or alkali seem to be alike suitable to its tastes. I have found this species hibernating in clay within five feet of the water of a river, and also in dryish sand fuily a hundred feet above the water level, with no water in the vicinity. Roadways, stubble fields, muddy flats and pure sand blowouts are where it is found most plentiful, but it is always where the vegetation is very scanty. It has been found in company with all the forms mentioned in this paper, and in the same hole as I2-guttata and limbalis while hibernating. It has also been found hibernating near all the other hibernating kind. The average depth of the winter hole in sandy land is 18 inches, deepest 24 inches, shallowest I I inches. In clay it averages $8 \mathrm{r} / 2$ inches, deepest 12 , shallowest 6 inches.

This species appears from pupa during the middle and latter part of August. In the spring it appears from its winter home with venusti as soon as the ground thaws out. It is one of the late species to hibernate.

Ants, small beetles, aphides and cutworms are among its food.

The form found in Manitoba is broadly marked, and has, until recently, been known as olliquato.

C. lonstilabris, aber. Montana, Lec.-Black or bronze above, with only a slight indenture to show where the middle band has been. In some this band is partly visible.

Montana inhabits bare spots on dark and dryish land; roadways are seemingly preferred. It has also been taken on ploughed fields, but nowhere plentifully. Unfortunately, I have been unable to secure this form in its winter home, though it undoubtedly hibernates. The new brood makes its appearance towards the end of July and begining of August. This form when disturbed usually flies into the grass, and is then easily captured.

C. obscura, aber. Lecontei, Hald.-This form in Manitoba usually has the markings all united so as to form a white margin. The colour varies from bright green to an iridescent-wine colour.

"Habits of American Cicindelide, p. 220 . 
Lecontei is found in dry situations. Sandy fields or the edges of drifting sand among sparse vegetation are its favourite spots. It is found in company with Manitoba, venusta and tranquebarica, but nowhere commonly. 'The new brood appears in August, and they begin to excavate their winter quarters early in September, being one of the first tiger-beetles to disappear. The burrows are nearly always made in very small openings, not more than a foot or so wide, surrounded by weeds, etc., being the least open locality of any of our forms or species, with the possible exception of Montana. The average depth of hole of a number measured, from the entrance, was 16 inches, the deepest being 22 inches and shallowest ro inches. The beetles appear again in the spring in April, at about the same time as venusta, and disappear late in July, about a week before the new brood appears. This form has been seen feeding upon cutworms.

C. punctulata, Oliv.-A summer species. Appears late in June and dies off towards the end of August. At Aweme it is found on old trails and on prairie where the grass is thin. Appears to be confined to a few spots, where it is usually plentiful.

The larvæ were found in holes on the prairie in small mossy. places between clumps of grass in dry situations, at an average depth of $2 \mathrm{I}$ inches, the deepest hole being 26 inches and the shallowest 18 inches. Most of the holes at this date (Oct. 7 ) were filled up tightly near the top, and again about four inches lower down, so that it was very difficult to push a grassstalk down them. As with other species, the larva "greatly exceed the beetles in numbers.

C. pusilia, Say.--This species is taken by Mr. L. E. Marmont, of Rounthwaite, which is only about 12 miles from Aweme. It occurs on roads and bare spots where the land is of a very black colour. Mr. Marmont takes pusilla in July and August. One he collected as late as the $24^{\text {th }}$ of August. No sign of the beetles could be found in June, and this fact, combined with the general appearance of the insect, leads me to the conclusion that it is probably a summer species that dies at the approach of winter.

Pusilla has also been taken by Mr. A. W. Hanhani at Bird's Hill, near Winnipeg. Mr. Hanham says, from his experience, pusilla never flies, but runs very rapidly, "easily disappearing off the trail into the long grass and so away." He adds that he only took two or three at the most. Mr. Marmont on one occasion caught a specimen in a pail of milk. 
The species varies in colour from dull green to black. There is also considerable variation in markings, some specimens being almost immaculate.

C. lepida, Dej--Only found on drifting sand planes, on sand, which they very closely resemble in colour. This is the weakest flier of any Manitoba tiger-beetle that I have collected, and towards the end of their season, at about the time when eggs are being deposited, the females make no attempt to fly, but are obliged to trust entirely to their running powers as a means of escape. They are usually found on the sunny side of a drifting sand-bank, where they get blown by the wind.

Lepida appears late in June, and is most numerous in July. It disappears towards the end of August. I have only once found it at all plentiful.

NOTES AND DESCRIP'TIONS OF MEMBRACIDA.

BY C. F. BAKER, ESTACION AGRONOMICA, SANTIAGO DE LAS VEGAS, CUBA.

\section{Centrotida.}

Gerridizs abbreviatus, n. sp.

Length, $4.5 \mathrm{~mm}$., male. General form and colour of G. scutellatus, but differing widely in the following characters: Legs mostly piceous ; the scutellar protuberance directed somewhat forward instead of backward; marks of tegmina arranged in the same pattern, but the oblique band at the middle of tegmina very broad and heavy, being three times as broad at middle of tegmina as at tip of clavus; tegmina with apical margin entirely fuscous, the larger spot at outer tip much broader than long. The most distinctive character lies in the form of the tegmina, which are much shorter than in $G$. scutellatus, the middle apical cell being two-thirds the length of the second discoidal cell, the same cell in $G$. scutellatus not being one-half of second discoidal.

I collected this interesting species at San Marcos, an Indian pueblo well up in the westem coast range of Nicaragua.

Ischnocentrus niger, Stal.

The small dark males and the iarger paler females (originally described as I. ferruginosus, Stal.) I found not uncommon at San Marcos, Grenada, and Chinandega in Nicaragua, these points all being far north of the records given in Biol. Cent. Amer.

Cyrtolobus Vanduzei, Godg.

SMILHDL:

This species. was formerly described by Goding under the genus Smilia, a genus noted especially for the great elevation of the pronotum April, 1907 